\title{
МЕЖЭТНИЧЕСКИЕ БРАКИ В СРЕДЕ ГОРОДСКИХ РУССКИХ И КАЗАХОВ СЕВЕРНОГО КАЗАХСТАНА
}

Статья посвящена анализу основных тенденций развития брачных отношений между городскими казахами и русскими Северо-Казахстанской области в 1996-2016 г2. Авторы ставят ичель не только показать происходящие количественные изменения в семейно-брачной сфере, они анализируют основные факторы, влияющие на общее развитие межэтнических браков. Показатели межэтнической брачности являются релевантными маркерами развития межэтнических отношений в иелом и позволяют проанализировать существующие этнокультурные дистанции. В этой связи основное внимание уделено бракам между представителями казахского и русского населения региона. Источниковой базой исследования стали материаль городского ЗАГСа и данные этносочиологических опросов. На основе опубликованных научных исследования был проведен сравнительный анализ с развитием семейно-брачных отношения в других регионах Казахстана.

Изучение межэтнических браков в указанный период выявило очевидное смещение психологических установок в позитивную сторону, как у местных казахов, так и у русских. В значительной степени это связано с ускоренной урбанизачией казахского населения и широкого распространения системы европейских социальных установок, включающей индивидуализачию сознания и превалирование эгалитарной семьи. На основе эмпирического материала прогнозируется дальнейшее увеличение количества браков казахов и русских в регионе. Несмотря на то, что основную долю браков в настоящее время составляют моноэтнические браки, этносочиологический опрос в апреле 2020 г. показал лояльное отношение большинства казахской и русской молодежи к вероятности создания семьи с представителями другого этноса. Исследование также выявило, что в Северном Казахстане два ведущих этноса

Казиев Саттар Шерниязович - д.и.н., доцент, Северо-Казахстанский государственный университет имени М. Козыбаева (Республика Казахстан, 150000 Петропавловск, ул. Жумабаева, 114). Эл. почта: Sattarkaz@mail.ru. Kaziev, Sattar S. - Dr. of Hist., North Kazakhstan State University named after M. Kozybaev (Petropavlovsk, Kazakhstan). E-mail: Sattarkaz@mail.ru

Могунова Марина Викторовна - старший преподаватель, Северо-Казахстанский государственный университет имени М. Козыбаева (Республика Казахстан, 150000 Петропавловск, ул. Жумабаева, 114). Эл. почта: M_mogunova@mail.ru. Mogunova, Marina V. - North Kazakhstan State University named after M. Kozybaev (Petropavlovsk, Kazakhstan). E-mail: M_mogunova@mail.ru

Могунов Сергей Викторович - старший преподаватель, филиал Академии государственного управления при Президенте Республики Казахстан по Северо-Казахстанской области (Республика Казахстан, 150000 Петропавловск, ул. Конституции Казахстана, 38). Эл. почта: Serzh1307@mail.ru. Mogunov, Sergey V. - Branch of the Academy of Public Administration under the President of the Republic of Kazakhstan in the North Kazakhstan Region (Petropavlovsk, Kazakhstan). E-mail: M_mogunova@mail.ru 
избежали варианта «общинизащии» и оказались «открытылми» в межэтнических отношениях, что в дальнейшем может нивелировать этнокультурные различия и блокировать межгрупповые конфликты. Данная тенденция выявлена пока на местном уровне и контрастирует с развитием семейно-брачных отношений в южном регионе, где заметна жесткость межэтнических «перегородок» и сила традиционных установок.

Ключевые слова: межэтнические браки, казахи, русские, межэтнические отношения

\section{Введение}

Казахстанское общество отличается исторически сложившимся значительным этническим и религиозным разнообразием. Еще в советский период возникли основные этнические макро-среды, в условных границах которых формировались специфические черты культуры и межгрупповых отношений. В южных районах сильно влияние среднеазиатской культурной традиции с ее установками на групповую солидарность и отрицательным отношением к бракам с представителями других этносов. Практически все этнические группы южных областей за исключением русских и русскоязычных этнических общностей поддерживают групповую сплоченность и солидарность действий, что является основным источником межэтнического недоверия и острых конфликтов. Жители северо-восточного региона на протяжении долгого времени находились в поле притяжения русско-европейской культурной традиции, что обусловило доминирование этнонациональной и гражданской форм солидарности. В совокупности это влияло на уровни интеграции казахстанского социума, маркерами которых является степень распространенности межэтнических браков между представителями двух крупнейших этносов Казахстана - казахов и русских.

Цель настоящего исследования - выявить тенденции развития казахско-русской брачности на протяжении длительного периода с середины 1990-х гг. и до наших дней и показать их взаимосвязь с изменениями в брачно-семейных отношениях на примере городских жителей Петропавловска. Выбор Петропавловска не случаен здесь исторически сложилась русско-казахско-смешанная этническая среда. Изменения этнодемографического состава населения и особенности протекания этносоциальных процессов последних 30 лет коснулись и межэтнических браков, в первую очередь отношения к таким бракам со стороны казахского населения.

Несколько слов об источниковой основе настоящего исследования. Изучение современных тенденций межэтнической брачности казахстанцев стало возможным благодаря работе с материалами архива Органов записи актов гражданского состояния (далее ЗАГС) г. Петропавловск Северо-Казахстанской области Республики Казахстан. Основным источником выступили актовые книги, которые составлены на основании государственной регистрации актовой записи о заключении брака. За основу настоящего исследования были взяты материалы актовых книг за 1996 г., 2006 г. и 2016 г. Информация актовых записей о заключении брака представляет научный интерес, поскольку согласно утвержденной форме, она включает сведения о возрасте, национальности, месте работы, образовании, семейном положении человека, вступающего в брак, данные об общих детях и т. п. Со временем в актовую запись специалистом ЗАГС вносится информация о расторжении брака. Основополагающими для 
настоящего исследования были характеристики, раскрывающие особенности брачного выбора казахов и русских в 1996-2016 гг. - возраст, место работы, образование.

Ценным источником стали материалы этносоциологических исследований, хотя к сожалению, такого рода исследований в предыдущие годы выполнялось довольно мало. Комплексный этносоциологический анализ установок на межэтническую брачность был проведен зимой 1994 г. в четырех регионах Казахстана сотрудниками Института этнологии и антропологи РАН им. Н.Н. Миклухо-Маклая в рамках программы «Язык, национальность и бывший Советский Союз». Социологический материал был получен авторами от М.Н. Губогло - со-руководителя данной программы. В статье также использовались данные социологических исследований казахстанских ученых разных лет и авторского обследования отношения студенческой молодежи к межэтническим бракам, проведенного в апреле 2020 г. в Петропавловске среди студентов Северо-Казахстанского государственного университета им. М. Козыбаева (далее СКГУ им. М. Козыбаева). В ходе опроса авторы сделали «срез» общественного мнения относительно межэтнических браков в молодежной среде. Всего было опрошено 216 студентов различных специальностей, в основном это были представители казахской и русской молодежи (ПМА 1).

\section{Обзор научной литературы}

Изучение межэтнической брачности в казахстанском обществе до распада СССР в значительной степени было связано с научным осмыслением интеграции советских народов в контексте их сближения и расцвета национальных культур. По мнению Д. Горенбурга, распространение межэтнических браков рассматривалось как ключевой фактор продвижений ценностей современного общества (Gorenburg 2006: 149). В статье американского исследователя Э. Эдгара и С. Уалиевой констатируется, что «в отличие от США и Европы, где довольно долго господствовало культурное неприятие смешанных браков, в СССР их поддерживали как в теории, так и на практике, поскольку смешанные браки способствовали окончательному слиянию наций в единый «советский народ». Межэтнические браки рассматривались как инструмент модернизации - особенно в таких «отсталых» регионах, как Средняя Азия» (Уалиева, Эдгар 2011: 236).

Огромный вклад в изучение особенностей межэтнических браков в бывшем СССР внесли этносоциологи Ю.В. Арутюнян, Л.М. Дробижева (Арутюнян и др. 1999), А.А. Сусоколов (Сусоколов 1987). Их труды оказали влияние и на подходы к исследованию межэтнических браков в Казахстане. В 1970-х гг. межэтнические браки городского и сельского населения Северного Казахстана исследовал Ю.А. Евстигнеев. Работа с широким кругом источников, особенно с регистрационными бланками ЗАГС, паспортных отделов позволила ученому выявить особенности межэтнической брачности на протяжении 1940-1969 гг. По его наблюдениям, этнически-смешанная брачность неодинакова среди этнических групп горожан. Ю.А. Евстигнеев отмечал высокий процент смешанных браков среди более малочисленных этносов, проживающих в городах севера Казахстана, поляков, белорусов, украинцев. Также он выяснил, что в смешанных браках преобладают мужчины у казахов, ингушей, корейцев, а женщины - у татар, немцев и русских (Евстигнеев 1973: 13). Ученый особо отметил распространение смешанных браков среди казахских женщин, связав 
это с «ослаблением зависимости от отсталых патриархальных традиций и обычаев не только у казахов, но и у соседних с ними народов» (Евстигнеев 1973: 15).

В постсоветский период семейно-брачные отношения городских казахов в 19501980-х гг. изучала А.Т. Абдулина. К числу основных тенденций данного периода исследователь отнесла браки казахов с представителями других культур. Рост межэтнической брачности части казахов она объясняла их установками на естественную ассимиляцию. «Всемерное распространение атеизма, ограничение ислама, <..> повышение культурно-образовательного уровня, интернационализация быта, ограниченность круга потенциальных брачных партнеров своей национальности, их «разбросанное» расселение в городе при общей невысокой численности, - все эти факторы привели к слому традиции строгой этнической эндогамии городских казахов и повышению межнациональной брачности» (Абдулина 2019). В качестве доминирующих брачных партнеров казахов исследователь называла татар и русских, отмечая существование этнокультурной близости между данными этническими группами. Характеризуя русско-казахские семьи, автор указала на их эгалитарность и демократизацию, отметив «некоторое нивелирование этничности супругов» (Абдулина 2019).

Работы А.Б. Калыша (А.Б. Калышева) освещают ситуацию межэтнической брачности в Казахстане в советский период и на современном этапе. Один из трудов ученого - монография «Семья и брак в современном Казахстане». Ценность ей придает использование автором широкого круга источников - полевых и статистических данных, архивных материалов ЗАГС и др. Интерес представляет ряд наблюдений А.Б. Калыша относительно этнически-смешанной брачности в Казахстане. Ученый отметил, что отношение современного поколения казахстанцев к национально-смешанным бракам во многом определяется этнической средой проживания. По мнению исследователя, заметно «по мере усложнения этнического состава населения более терпимое отношение к смешанным семьям» (Кальиш 2013: 328). По его данным «большинство смешанных семей создаются с участием русского, казахского и украинского этносов» (Кальиш 2013: 360). Говоря о брачных предпочтениях казахстанцев, исследователь констатировал, что «казахи при вступлении в национально-смешанные браки отдают предпочтение русским и татарам, а татары - казахам и русским» (Кальши 2013: 356). Еще одна закономерность, характерная для межэтнической брачности, касается малочисленных этносов Казахстана. Ученый пишет, что именно их представители чаще вступают в этнически-смешанные браки в силу своего численного меньшинства или дисперсного расселения (Кальиш 2013: 361).

Материалы по межэтнической брачности в современном казахстанском обществе представлены трудами С.К. Уалиевой, В.А. Козлова и др. Затрагивая на страницах своих работ разные аспекты межэтнической брачности, С.К. Уалиева отмечает и во многом подтверждает те тенденции смешанной брачности, которые ранее уже были отмечены авторами. Так, она фиксирует рост межэтнической брачности среди казахского населения, большую активность казахских мужчин при заключении этнически-смешанных браков, выявляет, что показатели межэтнической брачности среди русских практически не изменились. В то же время казахстанский исследователь замечает ряд интересных особенностей современного периода. Так, при высоких показателях межэтнической брачности среди казахских мужчин, показатели разводов в аналогичных браках выше у казашек. Русские Казахстана, в отличие от казахов, стали меньше разводиться, находясь в браке с представителем другой этнической группы (Уалиева 2008) 
В работе В.А. Козлова акцентируется внимание на предпочтениях в выборе партнера при вступлении в межэтнический брак и используется в качестве исследовательского инструмента метод межэтнического расстояния. В.А. Козлов проводит сравнительный анализ предпочтений в выборе партнера по браку в Казахстане и Эстонии. В ходе исследования автор приходит к интересному выводу, что при относительно схожем этническом составе населения постсоветских республик, межэтническая брачность в указанных странах характеризуется противоположными тенденциями. Так, ученый констатирует больше этнически-смешанных браков в Казахстане, чем в Эстонии. Среди причин, объясняющих формирование смешанных браков в Казахстане, автор указывает на брачные предпочтения внутри самих европейских и азиатских этносов, а также на наличие дополнительного «брачного рынка» в стране (Козлов 2017: 86). Текущая ситуация с брачностью, по мнению автора, характеризуется «достаточно большим этническим расстоянием» между казахами и русскими в сравнении с аналогичным показателем между эстонцами и русскими. В целом исследователь высказывает предположение, что в современном Казахстане «в будущем ... ожидаем отдаления национальностей по предпочтениям друг от друга в связи со снижением численности некоренных этносов» (Козлов 2017: 86).

На наш взгляд, изучение межэтнических браков показывают их роль как важных индикаторов проблем интеграции общества на современном этапе, что недостаточно изучено в научной литературе.

\section{Установки и реалии межэтнической брачности в Казахстане}

Определенно современные семейно-брачные отношения, как и обобщенное доверие, стали результатом советской политики создания нового общества, базовыми компонентами которого являлись вполне европейские установки на эгалитарную семью. Советская власть планомерно искореняла гендерное неравенство, традиции многоженства, уплату калыма и доминирование родовых отношений в Центральной Азии. Периодические кампании против пережитков прошлого в семейно-брачных отношениях достигли успеха в урбанизированной смешанной этнической среде с большой долей европейских групп населения, в случае Казахстана - русских, немцев и украинцев. Наибольшая концентрация их имела место в северо-восточном Казахстане и Алма-Ате. Здесь среди казахов получила распространение нуклеарная семья с ее индивидуализмом и относительной независимостью от мнения старшего поколения в выборе социальных стратегий и сопутствующих практик, что было связано с разрушением родовых связей. Фактически исчез обычай «салем салу», являющийся маркером неравноправия молодых женщин в расширенных неразделенных семьях.

В то же время в южных и западных областях Казахстана, прежде всего в сельской местности, доминировала расширенная многодетная семья и сохранилось значение культа предков и солидарная сплоченность внутри аулета (әулет)-потомков первопредка ${ }^{1}$. Весьма интересные данные о социальных отношениях внутри современных

${ }^{1}$ В этнологической литературе, посвященной казахскому обществу, социальная роль аулета (әулет) практически не раскрывается, в то время как они играют более весомую роль, чем родовые или жузовые начала, последние авторами настоящей статьи отнесены к категории «изобретенных» традиций. В отличие от северо-восточного региона казахи южных областей сохраняют консолидацию близких родственников. 
туркестанских ходжей и проникновении в их среду казахских установок на выбор брачных партнеров опубликовал А. Маликов. По его данным, проживающие рядом с казахами т.н. казахские ходжи заимствовали обычай «жеті ата» и не допускают близкородственные браки, давая согласие на браки с представителями племени конырат, в то время как у «узбекских ходжей превалируют близкородственные браки в отличие от казахоязычных. Хотя в этом вопросе у казахских ходжей есть некоторая доля сомнения ввиду того, что сам пророк выдал свою дочь за двоюродного брата - Али. Однако влияние чисто казахских традиций, не иметь родственников в семи коленах, оказывает влияние на казахоязычных ходжей... Некоторые ходжи женаты на не-ходжах и конечно их вторые половины осуждают близкородственные браки. Считают, что это вредно для генетики будущих поколений» (Маликов 2014: 41). Несмотря на это казахские ходжа или кожа сохраняют некоторую обособленность. В северных областях эндогамия чингизидов-торе и кожа была разрушена основательно с распространением русской культуры, и они беспрепятственно заключают браки с представителями других казахских родовых групп.

Несомненно, специфические черты этнокультурного развития отдельных групп казахского населения и формирования этнонациональной идентичности влияют на отношение к межэтническим бракам с представителями других народов. В северных областях уже в 1970-е гг. при заключении браков родовая принадлежность перестала играть какую-либо роль, тогда как ранее в Северо-Казахстанской и Кокчетавской областях браки заключались преимущественно между представителями родов атыгай, караул и социальной группы торе в одних случаях, керей и уак в других. Угроза ассимиляции в русскоязычной среде северных областей сместила конструирование этнических границ с родовых начал на этнонациональный уровень. Стремление казахов сохранить свою этническую идентичность способствовала прочности межэтнических «перегородок» в семейно-брачных отношениях, при этом собственно межэтнические отношения между казахами и русскими характеризовались высоким уровнем солидарности и доверия, чему способствовала совместная учеба и работа, служба в армии и т.д.

Релевантную картину дифференциации в отношении к межэтническим бракам русских и казахов дают материалы этносоциологического опроса 1994 г. в четыpeх крупных городах Казахстана (Алматы, Шымкент, Атырау и Петропавловск). На вопрос «Как бы Вы отнеслись к браку с человеком другой национальности Вашего сына?» в целом по Казахстану считали это нежелательным 36,7\% (389 чел.) опрошенных городских казахов, у русских - 22,5\% (251 чел.); предпочитали выбор невестки своей национальности, но не собирались возражать против выбора сына 29,7\% (310 чел.) казахских респондентов и 32\% (358 чел.) русских; в той или иной степени поддерживали позицию, что «национальность в браке значения не имеет» 29,5 \% (305 чел.) опрошенных казахов и 39,3 (436 чел.) опрошенных русских. Негативное отношение к межэтническим бракам усиливалось в случае вероятного брака дочери с представителем другой национальности. Категорически против таких браков выступали 41,8\% казахов и 25,8\% русских; предпочли бы моноэтнический брак $28,3 \%$ казахов и $31,8 \%$ русских. Значительно меньшая доля казахов $(22,3 \%)$ и русских $(36,1 \%)$ поддерживало возможность своего согласия на межэтнические браки. Большую роль в блокировании межэтнических браков играли установки старшего поколения, предпочитавшего моноэтнические браки у своих детей, апеллируя к необходимости поддержания национальных традиций. Зимой 1994 г. 61,6\% 
опрошенных казахов отметили необходимость получения родительского согласия на брак, еще 20,2\% выбрали «да, но не обязательно», лишь 10,6\% посчитали его необязательным и 7,6\% респондентов затруднились с ответом. Спустя четверть века каждый второй казахский студент, обучающийся в университете г. Петропавловск в 2020 г., проблемы межнациональных браков связывает с непониманием самого общества, родных $(45,1 \%)$. Другая часть современной казахской молодежи не видит никаких проблем в смешанной брачности $(41,2 \%)$. Среди русских студентов значительно число тех, кто не видит никаких сложностей с подобными браками (48,2\%). Каждый третий русский студент также отметил непонимание и упреки со стороны общества и родственников в качестве основных проблем межнациональной брачности (29,4\%). 22,4\% русских студентов акцентировали внимание на различии национальных, религиозных и прочих традиций, которые могут обернуться проблемами в межнациональном браке (ПМА 1).

В начале 2000-х гг. казахстанские ученые фиксировали снижение негативного отношения к межэтническим бракам среди казахов и русских. По данным 3. Шаукеновой на 2002 г., в южном регионе осуждали и готовы препятствовать межэтническим бракам 6,5\% опрошенных казахов и $0,9 \%$ русских; в северном регионе $-5,6 \%$ казахов и 2,7\% русских. Не одобряли межэтнические браки в южном регионе $27 \%$ казахов и $8,8 \%$ русских; в северном регионе - соответственно $28 \%$ казахов и $18 \%$ русских (Шаукенова 2002: 105). Смягчение установок на межэтническую брачность в значительной степени вызвано ускоренной урбанизацией казахского населения, способствовавшей ослаблению влияния в их среде родственных отношений и усилению контактов с городскими русскими.

Данные апрельского опроса студентов г. Петропавловск в 2020 г. показывают снижение доли негативного отношения к межэтническим бракам в молодежной среде. Мнение современных казахских студентов о межнациональных браках в целом положительное. Около 47,1\% казахов одобряют такого рода браки; каждый второй казахский студент рассматривает межнациональный брак как обычный брачный союз, 60\% русских студентов считают, что межнациональный брак есть, прежде всего, брак и только. Значительная часть русских студентов $(37,6 \%)$ высказала положительное отношение к бракам между представителями разных национальностей. Аналогичной позиции к межэтническому браку придерживаются и представители других этносов. Готовность вступить в брак с представителем другой национальности выразили $83,5 \%$ русских и 72,5\% казахских студентов. Любопытно, что позитивный настрой в отношении межэтнических браков совпадает с достаточно высоким уровнем межэтнического доверия в студенческой среде. Доверие к представителям другой национальности высказало $45,1 \%$ студентов-казахов и 51,8\% русских. Относительность национальной принадлежности указали 54,9\% казахских и 48,2\% русских и 62,1\% студентов - представителей других этносов (ПМА 1). Данный тренд в молодежной среде в будущем, вероятно, станет доминирующем по мере углубления урбанизации казахов и усиления их смешивания с представителями других этнических групп. В настоящее время городские казахи и русские испытывают влияние культурных дистанций на межэтнические браки. Интерес представляет сопоставление установок на межэтнические браки с реальной картиной. В этой связи уместно обратиться к анализу материалов ЗАГСа в г. Петропавловске. 


\section{Межэтнические браки в Петропавловске в 1996 г., 2006 г. и 2016 г.}

Согласно материалам актовых книг архива ЗАГС количество официально оформленных браков в г. Петропавловске увеличивалось от десятилетия к десятилетию (1996-2016 г.) (табл. 1). Более высокие темпы брачности наблюдаются с 1996 г. по 2006 г. Актовые записи содержат упоминание о том, что брак порой заключался между людьми, не имеющими городской прописки.

Таблица 1

Браки, зарегистрированные в г. Петропавловск (количество браков)

\begin{tabular}{c|c|c|c|c}
\hline \multirow{2}{*}{ Годы } & \multicolumn{4}{|c}{ Браки, зарегистрированные гор ЗАГС г. Петропавловск } \\
\cline { 2 - 5 } & Всего & Моноэтнические & $\begin{array}{c}\text { Этнически- } \\
\text { смешанные }\end{array}$ & $\begin{array}{c}\text { Не указана этничность } \\
\text { одного или обеих } \\
\text { брачующихя }\end{array}$ \\
\hline 1996 & 1157 & 879 & 278 & - \\
\hline 2006 & 1738 & 1269 & 358 & 111 \\
\hline 2016 & 1908 & 1371 & 437 & 140 \\
\hline
\end{tabular}

* Таблица составлена по материалам: Департамент 1996; Департамент 2006; Департамент 2016

Брачные союзы, зарегистрированные в г. Петропавловск, разноплановы. Подавляющее большинство браков являются моноэтничными. Архивные материалы свидетельствуют, что с каждым новым десятилетием моноэтничность при заключении городских браков снижается, хотя и незначительно. В середине 90-х гг. моноэтничные браки составили 75,5\%, в середине нулевых гг. - 73\%, в 2016 г. - 71,8\% от общего числа всех городских браков (табл. 1). Имеют место и браки, в которых не указана этничность одного или обоих брачующихся. В таких случаях актовые записи содержат лишь сведения о гражданстве людей, вступающих в брак. В актовых записях 1996 г. упоминания о подобных брачных союзах не содержатся. С 2006 г. по 2016 г. количество браков, в которых у брачующегося (-хся) не указана этническая принадлежность, уже существенно (табл. 1).

Пристальный интерес вызывают браки, которые объединяют представителей разных этносов, или этнически-смешанные браки. На протяжении 1996-2016 гг. этнически-смешанным был каждый четвертый/пятый брак, заключенный в г. Петропавловске. Со временем количество полиэтничных браков растет, однако их удельный вес в общей структуре браков снижается (табл. 1). Феномен этнически-смешанного брака интересен, прежде всего, с точки зрения выбора брачного партнера. Настоящее исследование сфокусировано на браках между мужчинами казахами и русскими женщинами, зарегистрированными в разные годы.

Интерес к казахско-русским бракам во многом обусловлен статусом одной из этнических групп как государствообразующего (титульного) этноса. Кроме того, данные этнические группы задают тон в формировании городской этнической среды, которая накладывает отпечаток на все общественное взаимодействие. На протяжении 1996-2016 гг. соотношение казахов и русских в г. Петропавловск менялось 
(табл. 2). Тем не менее, в этнической структуре населения города длительное время продолжало доминировать русское население. Подобное обстоятельство позволяет говорить о складывании и существовании здесь русско-казахской этнической среды.

Таблица 2

\section{Русско-казахская этническая среда г. Петропавловск Северо-Казахстанской области (чел.)}

\begin{tabular}{c|c|c|c}
\hline Годы & Всего & Казахи & Русские \\
\hline 2006 г. & 190950 & 35323 & 133173 \\
\hline 2016 г. & 216306 & 59690 & 133936 \\
\hline
\end{tabular}

* Таблица рассчитана по источнику: Динамика 2020

Соответственно в рамках столь специфической этносреды шансы на заключение брачных союзов среди представителей двух этносов, даже при наличии серьезных культурных различий, высоки. Согласно архивным материалам на протяжении десятилетий число браков между казахами и русскими росло, причем более заметно с 1996 г. по 2006 г. (табл. 3). Также по материалам ЗАГС, мужчины казахи чаще, чем женщины казашки, выбирали в качестве брачного партнера представителя русского этноса. Наконец, не брались в расчет браки между казахами и татарами, русскими и украинцами, русскими и немцами и пр., так как, в общем, картина межэтнической брачности в г. Петропавловск не меняется.

Таблица 3

\section{Браки, зарегистрированные между казахами и русскими в г. Петропавловск} (человек)

\begin{tabular}{c|c|c|c}
\hline Годы & Казахско-русские & Русско-казахские & Итого \\
\hline 1996 г. & 11 & 4 & 15 \\
2006 г. & 33 & 19 & 52 \\
2016 г. & 49 & 29 & 78 \\
\hline
\end{tabular}

* Таблица составлена по материалам: Департамент 1996; Департамент 2006; Департамент 2016

Материалы настоящего исследования показывают, что брачные пары между казахами и русскими женщинами, создаются в разном возрасте. В 1996 г. самым «юным» молодоженом оказался 20-тилетний мужчина, самым возрастным - казах 61 г. Пик брачной активности у городских казахов приходился на период 20-24-х лет. Средний возраст, в котором мужчины в 1996 г. вступали в брак, составил 27,36 лет (табл. 4). Брачная активность русских женщин в казахско-русских браках наблюдается до 30-летнего возраста, особенно ярко выражена в 20-24 года, 25-29 лет и 18-19 лет. Последнее обстоятельство подкрепляют показатели среднего брачного возраста, который у русских женщин в браках с казахами в 1996 г. достиг 26,18 лет (табл. 4). Вместе с тем, самой возрастной брачующейся стала женщина 57-и лет, что является скорее исключением, чем общей тенденцией, так как речь идет о браке между казахом 61 года и русской 57 лет. 
Таблица 4

Средний возраст вступления в казахско-русский брак (в годах)

\begin{tabular}{l|c|c|c}
\hline Средний возраст вступления в брак & $\mathbf{1 9 9 6}$ г. & $\mathbf{2 0 0 6}$ г. & $\mathbf{2 0 1 6}$ г. \\
\hline Мужчины казахи & 27,36 & 29,81 & 29,22 \\
\hline Женщины русские & 26,18 & 25,39 & 27,24 \\
\hline
\end{tabular}

* Таблица составлена по материалам: Департамент 1996; Департамент 2006; Департамент 2016

Спустя десятилетие (2006 г.) казахи чаще вступали в брак в 25-29 лет, 30-34 года и 20-24 года (по убыванию). После 40 лет наблюдается снижение брачной активности мужчин. Тем не менее, средний возраст мужчин, заключивших казахско-русский брак, по сравнению с 1996 г. незначительно повысился и составил 29,81 лет (табл. 4). В 2006 г. возрастной диапазон при заключении брака среди женщин варьировался от 18 до 51 года. Чаще всего русские женщины вступали в брак в 20-24 года. Средний возраст русских женщин, избранниц казахских мужчин в этом же году, несколько снизился по сравнению с 1996 г. (25,39 лет) (табл. 4).

В 2016 г. средний возраст вступления в брак мужчин казахов не изменился, остался в пределах 29 лет (табл. 4). В этом году казахи заключали браки до 59 лет включительно. Причем значительная часть браков с участием мужчин приходится на 2024-летний период их жизни. Ситуация с женщинами несколько иная: по сравнению с 2006 г. средний брачный возраст русских женщин увеличился и достиг 27,24 лет (табл. 4). Претерпели изменения и «крайние полюса» вступления в брачные отношения среди женщин: низкий - 17 лет и высокий - 60 лет. В 2016 г. встречались, так называемые ранние браки, браки с участием женщин моложе 18 лет. В целом русские женщины чаще всего выходили замуж в 20-24-летнем возрасте.

Еще одна деталь, характеризующая казахско-русские браки, касается соотношения возрастов брачных партнеров. В большинстве казахско-русских браков, заключенных в 1996 г., наблюдается возрастная разница в пользу мужчин. В полиэтничных парах преобладает 8-летняя разница в возрасте. В браках, в которых русская женщина старше своего партнера, разница в возрасте ниже (до 5 лет) (табл. 5). Образование брачных пар одного возраста встречается редко.

Таблица 5

Разница в возрасте в казахско-русских браках (количество браков)

\begin{tabular}{l|c|c|c}
\hline Разница в возрасте & $\mathbf{1 9 9 6}$ г. & $\mathbf{2 0 0 6}$ г. & $\mathbf{2 0 1 6}$ г. \\
\hline Мужчина казах старше & 7 & 24 & 32 \\
\hdashline Женщина русская старше & 3 & 7 & 11 \\
\hdashline Возраст мужчины казаха и русской женщины в браке совпадает & 1 & 2 & 6 \\
\hdashline Итого & 11 & 33 & 49 \\
\hline
\end{tabular}

* Таблица составлена по материалам: Департамент 1996; Департамент 2006; Департамент 2016 
В казахско-русских браках 2006 г. возрастной перевес также сохраняется в пользу мужчин (табл. 5). В среднем казахский мужчина старше избранницы от 1 до 6 лет, тогда как максимальная разница в паре составила 22 года. В этом же году возникло значительно меньше семейных пар, в которых женщина была старше своего партнера. Возрастной интервал в пользу женщины колеблется от 1 до 5 лет. Интересной особенностью подобных браков является то, что средний возраст казахских мужчин выше аналогичного возраста русских женщин, 31,87 год и 25 лет соответственно.

В большинстве казахско-русских браков 2016 г. мужчина казах старше по возрасту своей второй половины (табл. 5). В среднем разница между брачными партнерами в 4,16 г. Тем не менее, в архивных материалах встречается упоминание о этнически-смешанной паре с разницей в 14 лет. В том же 2016 г. встречались браки, в которых возрастной перевес был в пользу русской женщины, в среднем на 3,1 года. Самая заметная разница в подобных парах составила 9 лет. Причем средний возраст казахов в смешанных браках выше среднестатистического (32 года), равно как и средний возраст самих женщин (35,1 года). В 2016 г. незначительно число браков с одинаковыми по возрасту брачными партнерами. В этом случае средний возраст брачующихся составил 25,67 лет.

Таким образом, структура казахско-русских браков по возрастному критерию разнообразна. Городские казахи и русские женщины вступали в брак в разном возрасте. Причем, в большинстве случаев для русских горожан заключаемый брак первый. Ранние браки получили распространение среди русских горожанок. В то же время казахские мужчины вступали в семейно-брачные отношения в зрелом возрасте. Последнее обстоятельство подкрепляют показатели среднего брачного возраста мужчин и женщин. В современных этнически-смешанных парах мужчина традиционно старше женщины. В тоже время перестают быть редкостью брачные союзы, в которых русская женщина старше своего избранника.

Выше обозначенные тенденции в свою очередь сказываются на уровне образования брачующихся. В 1996 г. образовательный уровень мужчин казахов был неоднороден. Это обстоятельство подтверждают данные о распределении горожан-мужчин по образовательным ступеням. Так, у казахских мужчин из казахско-русских браков преобладало среднее специальное образование (табл. 6). Средним специальным образованием охвачены в основном молодые мужчины. Это лица возрастной группы 20-24 года и один мужчина 34 лет. Ситуация с образованием русских женщин аналогична (табл. 6). При этом русские женщины, имеющие среднее специальное образование, относятся к возрастной группе 25-29 лет.

В 2006 г. образовательный уровень казахских мужчин значительно повысился. Почти каждый второй мужчина, состоящий в казахско-русском браке, указал в соответствующей графе анкеты «высшее образование» (табл. 6). Это казахи-горожане 20-24, 25-29 и 30-34 лет. Количество казахов со средним специальным образованием практически не поменялось по сравнению с предыдущим десятилетием (табл. 6). Претерпел изменения возраст казахских мужчин, имеющих среднее специальное образование - это горожане 25-29, 20-24 и 30-34 лет (по убыванию). Русские женщины 20-24, 25-29 и 30-34 лет, состоящие в браках с казахами, чаще указывали наличие среднего специального образования (табл. 6). По сравнению с 1996 г. число русских горожанок со средним специальным образованием выросло, их возрастной диапазон стал намного шире. 
Образование партнеров в казахско-русских браках (в браках)

\begin{tabular}{|c|c|c|c|c|c|c|}
\hline \multirow[b]{2}{*}{ Образование } & \multicolumn{2}{|c|}{1996 г. } & \multicolumn{2}{|c|}{2006 г. } & \multicolumn{2}{|c|}{2016 г. } \\
\hline & 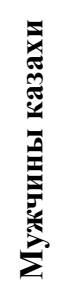 & 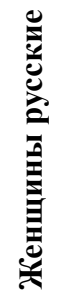 & 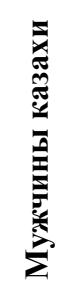 & 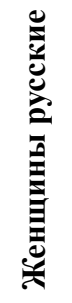 & 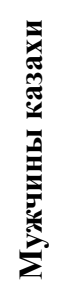 & 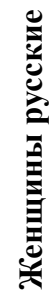 \\
\hline Высшее & 1 & 1 & 18 & 9 & 20 & 14 \\
\hline Незаконченное высшее & 2 & 2 & 1 & 1 & 2 & 3 \\
\hline Среднее специальное & 5 & 5 & 6 & 13 & 19 & 21 \\
\hline Среднее общее & 2 & 2 & 7 & 8 & 6 & 9 \\
\hline Неполное среднее & 1 & 1 & 1 & 2 & 2 & 2 \\
\hline Начальное и ниже & - & - & - & - & - & - \\
\hline Итого & 11 & 11 & 33 & 33 & 49 & 49 \\
\hline
\end{tabular}

* Таблица составлена по материалам: Департамент 1996; Департамент 2006; Департамент 2016.

В 2006 г. образовательный уровень казахских мужчин значительно повысился. Почти каждый второй мужчина, состоящий в казахско-русском браке, указал в соответствующей графе анкеты «высшее образование» (табл. 6). Это казахи-горожане 20-24, 25-29 и 30-34 лет. Количество казахов со средним специальным образованием практически не поменялось по сравнению с предыдущим десятилетием (табл. 6). Претерпел изменения возраст казахских мужчин, имеющих среднее специальное образование - это горожане 25-29, 20-24 и 30-34 лет (по убыванию). Русские женщины 20-24, 25-29 и 30-34 лет, состоящие в браках с казахами, чаще указывали наличие среднего специального образования (табл. 6). По сравнению с 1996 г. число русских горожанок со средним специальным образованием выросло, их возрастной диапазон стал намного шире.

В 2016 г. за плечами казахских мужчин, за некоторым исключением, был вуз либо колледж. Казахи мужчины 25-29 и 30-34 лет имели диплом о высшем образовании. Среднее специальное образование характерно для мужчин преимущественно 2024 лет. При вступлении в брак с казахом, каждая вторая русская женщина указала среднее специальное образование. Как правило, русские горожанки были в возрасте 20-24 и 25-29-ти лет. Каждая четвертая женщина из полиэтнического брака отметила наличие высшего образования в основном в возрасте 20-24, 30-34 и 25-29 лет (табл. 6).

В то же время материалы исследования показывают, что ситуация с образованием партнеров по браку меняется (табл. 7). В каждом втором казахско-русском браке 1996 г. мужчина и женщина имели одинаковое образование, чаще всего среднее, в основном среднее общее и среднее специальное (табл. 7). Наряду с этим наблюдался и некий образовательный паритет. Браков, в которых казахские мужчины имели выше образование, было столько же, сколько и браков, в которых было выше образование русских женщин (табл. 7). 


\section{Соотношение уровня образования мужчины казаха и \\ русской женщины в браках}

\begin{tabular}{|c|c|c|c|}
\hline Соотношение уровня образования & 1996 г. & 2006 г. & 2016 г. \\
\hline Образование мужчины казаха выше & 3 & 11 & 14 \\
\hline Образование женщины русской выше & 3 & 4 & 11 \\
\hline Образование мужчины-казаха и русской женщины совпадает & 5 & 18 & 24 \\
\hline Итого & 11 & 33 & 49 \\
\hline
\end{tabular}

* Таблица составлена по материалам: Департамент 1996; Департамент 2006; Департамент 2016

В 2006 г. сохранялась тенденция на одинаковость образования в казахско-русских браках. Практически в каждом втором этнически-смешанном браке образование мужчины и женщины совпадало. С дипломом о высшем образовании в основном были оба партнера (табл. 7). В каждом третьем смешанном браке образование мужчины казаха было выше образования русской женщины (высшего образования) (табл. 7). Интересной деталью является то, что в большинстве брачных случаев мужчина казах был старше своей спутницы жизни. В полиэтничных парах того же года, в которых русская женщина была старше партнера, чаще образование брачующихся совпадало в пользу среднего специального образования.

В 2016 г. в каждом втором казахско-русском браке партнеры имели одинаковое образование, преимущественно высшее. В каждом четвертом смешанном браке образовательный уровень мужчины был выше (табл. 7).

В целом на протяжении 1996-2016 гг. образование казахов и русских, оформивших браки в г. Петропавловск, было довольно разным. Среди молодоженов встречались лица, имевшие как неполное среднее, так и высшее образование, но преобладало распространение среднего специального и высшего образования. В казахско-русских парах на протяжении этих десятилетий сохранялась тенденция к общности образовательного уровня.

Этнически-смешанный брак также интересен с точки зрения социально-профессионального статуса брачных партнеров. Казахи и русские, вступившие в брак в 1996-2016 гг., принадлежали к разным профессиональным стратам. Длительное время казахи и русские были вовлечены в деятельность различных сфер городского хозяйства г. Петропавловск. По материалам архива ЗАГС в середине 90-х гг. среди казахских мужчин было немало людей рабочих профессий - монтер пути, животновод, слесарь на заводе. Русские женщины реализовывали себя в качестве медицинских работников, лаборантов, продавцов, заготовщиц, укладчиц и пр. В это же время появлялись частные предприниматели из числа мужчин и женщин. В 2006 г. круг мужских профессий несколько изменился. Трудовая занятость казахов предполагала более высокую, чем прежде, квалификацию. Казахские мужчины представлены специалистами, инженерами, военными, менеджерами, преподавателями. Значительное число русских женщин, на момент заключения брака с мужчинами казахами, временно не работали. В 2016 г. казахи мужчины имели отношение к государственной службе, к сфере образования (учителя, преподаватели) и здравоохране- 
ния (врачи) и пр. Заметное число казахов при заключении казахско-русских браков указало профессию «рабочий». Русские женщины чаще характеризовали себя как работники сферы торговли и услуг. Также приложение женского труда было связано со сферой образования, здравоохранения и культуры (учителя, психологи, воспитатели, социальные работники, актеры). Обращает внимание заметное число безработных русских женщин.

В целом, изучение казахско-русских браков позволило определить основные динамические изменения в брачных установках данных этнических групп на протяжении последних 20 лет, среди которых наибольшего внимания заслуживают следующие:

1. В исследуемый период прослеживается тенденция устойчивого роста заключения казахско-русских браков. Увеличение данного показателя в более чем 4,5 раза свидетельствует об интенсивной динамике в сфере межэтнической брачности. По нашему мнению, данная тенденция объясняется с одной стороны, изменениями, которые произошли за 20 лет в этнической среде города (рост казахского населения), с другой стороны, с этнической дестереотипизацией брачных установок;

2. В течение двух десятилетий в казахско-русских союзах наблюдается рост, так называемой, отложенной брачности. Увеличение возраста брачующихся, на наш взгляд, не имеет прямого отношения к этничности, а скорее всего, является следствием активно идущего в казахстанском обществе процесса трансформации общественного сознания, одним из показателей которого, является увеличение возраста вступления в брак в целом по стране;

3. Несмотря на продолжающееся доминирование брачного стереотипа «муж должен быть старше жены», в казахско-русских браках, за исследуемый период фиксируется значительный рост (более чем в 3 раза) браков, в которых женщина старше. На наш взгляд, это связано, с тем, что русские женщины вступают в брак позже из-за проблем с получением высшего образования, профессиональным ростом и индивидуализацией выбора партнера;

4. В казахско-русских браках значительно растет образовательный уровень брачных партнёров. Данное обстоятельство во многом объясняется деэлитизацией высшего образования в стране и ростом отложенной брачности. Кроме того, прослеживается тенденция общности образовательного уровня;

5. Для казахско-русских браков характерна социально-профессиональная неодинаковость партнёров. Мужчины и женщины, заключившие казахско-русские браки, всё чаще принадлежат к разным социально-профессиональным группам.

\section{Заключение}

Анализ развития межэтнической брачности в Северном Казахстане на примере городских жителей г. Петропавловска позволяет сделать определенные выводы относительно наблюдаемых тенденций. Если взглянуть на различия в психологических установках и увеличение числа межэтнических браков в период между серединой 1990-х гг. и второй половиной 2010-х гг., очевидно постепенное разрушение «перегородок» и стирание различий между русскими и казахами в семейно-брачной сфере. Ускоренная урбанизация и связанная с ней «вестернизация» социального сознания способствуют нивелированию традиционалистских установок и сокра- 
щают этнокультурные дистанции. Большое значение имеет положительный опыт советской национальной политики, направленной на социокультурное сближение советских народов. Для современной казахской молодежи г. Петропавловска знание традиций казахского народа представляет форму исторического сознания, а не социальный императив, определяющий их образ жизни и модель должного поведения. Соответственно, в перспективе следует ожидать постепенного увеличения казахско-русских браков.

Определенно можно сказать и о влиянии на рост межэтнических браков взаимно толерантного отношения представителей двух основных этносов региона - русских и казахов. Несмотря на отсутствие за годы независимости внятной национальной политики, в регионе не сформировались замкнутые этнические общины, за исключением кавказских и среднеазиатских диаспор. «Открытость» основных этносов региона - русских, казахов, украинцев, немцев и татар, способствует как интеграции населения, так и дальнейшему распространению межэтнических браков. Тем не менее, нельзя игнорировать того, что преобладание этнической эндогамии со стороны казахов и заключение русскими браков только с русскими партнерами или с представителями т.н. «европейских» этнических групп сохранится из-за определенной инерции этносоциального развития и усиления дифференцирующих факторов, таких как религиозные различия, языковые проблемы, организованная миграция казахов из южных областей и отток русского населения.

\section{Источники и материалы}

ПМА 1 - Полевые материалы авторов Казиева С.Ш., Могунова С.В., Могуновой М.В. Петропавловск. Апрель 2020 г.

Департамент 1996 - Департамент юстиции Северо-Казахстанской области Министерства юстиции Республики Казахстан. Архив ЗАГС. Актовая книга государственной регистрации актов гражданского состояния, составленная на основании актовой записи о заключении брака (супружества). Петропавловск. 1996 г.

Департамент 2006 - Департамент юстиции Северо-Казахстанской области Министерства юстиции Республики Казахстан. Архив ЗАГС. Актовая книга государственной регистрации актов гражданского состояния, составленная на основании актовой записи о заключении брака (супружества). Петропавловск. 2006 г.

Департамент 2016 - Департамент 2016 - Департамент юстиции Северо-Казахстанской области Министерства юстиции Республики Казахстан. Архив ЗАГС. Актовая книга государственной регистрации актов гражданского состояния, составленная на основании актовой записи о заключении брака (супружества). Петропавловск. 2016 г.

Динамика 2020 - Динамика основных социально-экономических показателей. Демографическая статистика. Динамика численности населения. //https://stat.gov.kz/region/264023/ dynamic (дата обращения: 29.03.2020).

\section{Научная литература}

Абдулина А.Т. Особенности семьи и брака и этноязыковая ситуация в среде городских казахов в конце 1950-1980-х гг. //http://edu.e-history.kz/kz/publications/view/800 (дата обращения: 07.04.2020).

Арутюнян Ю.В., Дробижева Л.М., Сусоколов А.А. Этносоциология. Москва: Аспект-Пресс, 1999.

Евстигнеев Ю.А. Динамика межэтнических браков в среде населения Северного Казахстана (1940-1969 гг.). Автореф. Дисс. канд. ист. наук. М., 1973. 
Кальши А.Б. Семья и брак в современном Казахстане: Монография. Алматы: Арыс, 2013.

Козлов B.A. Казахстан и Эстония: оценка предпочтений при вступлении в межнациональные браки // Населении и экономика. 2017. Т. 1. С. 71-88.

Маликов А.М. Ходжи Южного Казахстана: история и идентичность// https://www.researchgate. net/publication/325105859 (дата обращения: 14.03.2020).

Сусоколов А.А. Межнациональные браки в СССР. Москва: Мысль, 1987.

Уалиева С.К. Межэтнические браки в Казахстане и дети // http://www.demoscope.ru/ weekly/2011/0451/analit04.php (дата обращения: 07.04.2020).

Уалиева С.К., Эгдар Э. Межэтнические браки, смешанное происхождение и «дружба народов» в советском и постсоветском Казахстане // Неприкосновенный запас. 2011. № 6. С. 234-244.

Шаукенова 3.К. Социальное взаимодействие этносов в современном казахстанском обществе. - Астана: Парламент РК, 2002.

Gorenburg D. Rethinking Interethic Marriage in the Soviet Union //Post- Soviet Affairs. 2006. Vol. 22. No. 2. Pp. 145-165.

\section{References}

Abdulina, A.T. 2019. Osobennosti sem'i i braka i etnoyazykovaya situatsiya $v$ srede gorodskikh kazakhov $v$ kontse 1950-1980-kh [Features of family and marriage and the ethnolinguistic situation among urban Kazakhs in the late 1950s and 1980s.]. Edu.e-history.kz. http://edu.e-history. $\mathrm{kz} / \mathrm{kz} /$ publications/view/800.

Arutyunyan, Yu.V., L.M. Drobizheva, and A.A. Susokolov. 1999. Etnosotsiologiya [Ethnosociology]. Moscow: Aspekt-Press.

Gorenburg D. 2006. Rethinking Interethic Marriage in the Soviet Union. Post- Soviet Affairs 22 (2): $145-165$.

Evstigneev, Yu. A. 1973. Dinamika mezhetnicheskikh brakov v srede naseleniya Severnogo Kazakhstana (1940-1969 gg.) [Dynamics of interethnic marriages among the population of Northern Kazakhstan (1940-1969)]. PhD diss. Moscow State University.

Kalysh, A.B. 2013. Sem'ya i brak v sovremennom Kazakhstane [Family and marriage in modern Kazakhstan]. Almaty: Arys.

Kozlov, V.A. 2017. Kazakhstan i Estoniya: otsenka predpochtenii pri vstuplenii v mezhnatsional'nye braki [Kazakhstan and Estonia: Assessing Preferences for Interethnic Marriages]. Naselenii i ekonomika 1: 71-88.

Malikov, A.M. 2014. Khodzhi Yuzhnogo Kazakhstana: istoriya i identichnost' [Khoji of South Kazakhstan: History and Identity]. Researchgate.net. https://www.researchgate.net/publication/325105859.

Shaukenova, Z.K. 2002. Sotsial'noe vzaimodeistvie etnosov v sovremennom kazakhstanskom obshchestve [Social interaction of ethnic groups in modern Kazakhstani society] Astana: Parlament RK.

Susokolov, A.A. 1987. Mezhnatsional'nye braki v SSSR [Interethnic marriages in the USSR] Moscow: Mysl'.

Ualieva, S.K. 2011. Mezhetnicheskie braki v Kazakhstane i deti [Interethnic marriages in Kazakhstan and children] Demoscope.ru. http://www.demoscope.ru/weekly/2011/0451/analit04.php.

Ualieva, S.K., and E. Egdar. 2011. Mezhetnicheskie braki, smeshannoe proiskhozhdenie i «druzhba narodov» v sovetskom i postsovetskom Kazakhstane [Interethnic marriages, mixed origin and "friendship of peoples" in Soviet and post-Soviet Kazakhstan] Neprikosnovennyi zapas 6: 234-244. 
Kaziev Sattar S., Mogunova Marina V., Mogunov Sergey V.

\section{Inter-ethnic marriages among Russians and Kazakhs in the cities of Northern Kazakhstan}

The article discusses the main trends in the marriage relations between urban Kazakhs and Russians in the North Kazakhstan region in the period between 1996 and 2016. The authors aim not only to show the quantitative changes taking place in the field of family and marriage, but also to analyze the main factors that affect the overall development of inter-ethnic marriages. Inter-ethnic marriages are relevant predictors of the inter-ethnic relations in general and allow to assess the existing ethno-cultural distances. In this regard, the main attention was paid to marriages between Kazakhs and Russians of the region. The research was based on the materials of the City Civil Registry Office as well as on the ethnosociological surveys. A comparative analysis of the development of family and marriage relations in other regions of Kazakhstan was made based on data from published literature.

The study of inter-ethnic marriages between 1996 and 2016 revealed an obvious positive shift in the attitudes both among local Kazakhs and Russians. This is largely due to the accelerated urbanization of the Kazakh population and the widespread system of European social attitudes, including individualization of conscience and the prevalence of the egalitarian family. Based on empirical data, further increase in the number of marriages of Kazakhs and Russians in the region is predicted. Despite the fact that the main share of marriages is currently mono-ethnic marriages, an ethno-sociological survey in April 2020 revealed a tolerant attitude of the majority of Kazakh and Russian youth to the idea of creating a family with representatives of another ethnic group. The study also demonstrated that in Northern Kazakhstan, the two leading ethnic groups avoided the scenario of "communization" and turned out to be "open" in inter-ethnic relations, and in future, this can level out ethno-cultural differences and block inter-group conflicts. This trend has been identified so far at the local level and contrasts with the trends of family and marriage relations in the southern region, which show the rigidity of inter-ethnic "partitions" and the strength of traditional attitudes.

Keywords: inter-ethnic marriages, Kazakhs, Russians, inter-ethnic relations 